\title{
WHAT PRICE FUELWOOD?
}

\author{
By J. C. VeNESS, \\ Woodi Fuel Advisor, Wartime Prices and Trade Board
}

$\mathrm{O}$ N December 7, 1941, fuelwood was placed under the Wartime Prices and Trade Board in an endeavour to control the price of this commodity. Actually the basic period prices-or those prices prevailing during the period September 15 to October 11, 1941,- were to be maintained.. Unfortunately, during the period between the basic period and December 7, prices of fuelwood climbed steadily. Because most wood sales are made previous to September 15 and after October 11, it was impossible to set reliable basic prices. It, therefore, became necessary to set ceiling prices for fuelwood, reasonable to the producer and consumer, and this control was placed under the Coal Administrator. Someone had to take on this job and it fell to me to do so.

Of all the businesses which come under the control of the Board I am sure there is none as little organized as the fuelwood trade. It is one based on large numbers of producers ranging from the contractor who cuts thousands of cords to the farmer who, in his off winter season, may cut from 10 to 50 or more cords. Taken as a whole, the fuelwood business is a big one. It is estimated that the per capita consumption for the whole of Canada is $4 / 5$ of a cord, or a total Canadian consumption of approximately $9,000,000$ cords. This figure includes all grades of wood fuel, body hardwood, body softwood, and the different types of mill waste.

What complicates the problem of price control for wood fuel is the difference in local practices. Each locality has its grades and system of measurement. Neither has been standardized in the past. Municipal bylaws controlled measurement and have for the most part favoured the dealer at the expense of the consumer.

In the larger centres municipal by-laws have allowed the delivering of 100 cubic feet in short lengths of 12 " or $16^{\prime \prime}$ as a cord of wood. In other words, the standard cord in many cities applies only to 4 foot wood. It is a known fact that a cord of 4-foot wood will not produce 128 cubic feet of wood in short lengths. This shrinkage is due to the closer piling of this small material and may vary from 3 per cent to 15 per cent according to the type of material cut. Seldom does this shrinkage reach as much as $28 \mathrm{cu}$. $\mathrm{ft}$. to the cord, but generally this amount has been allowed by municipalities. When a cord of $12^{\prime \prime}$ wood is ordered, the dealer, of course, -being honest-goes to the pile of $4-\mathrm{ft}$. wood, carefully measures a cord, saws it and delivers the 12 " wood derived therefrom. I am afraid that the consumer has in the past received less than his due, and many dealers have delivered the minimum quantity allowed by the by-law. In other words, in many localities a cord of $4 . \mathrm{ft}$. wood contains $128 \mathrm{cu}$. $\mathrm{ft}$., but a cord of $12^{\prime \prime}$ or $16^{\prime \prime}$ wood contains only $100 \mathrm{cu}$. ft.

Practices differ in provinces. In Quebec, for example, most fuelwood is cut in $36^{\prime \prime}$ lengths. A cord may mean anything, as it is purely a face measurement. A pile of wood 8 feet $x 4$ feet by any length up to 4 feet 
is called a cord. A cord of $16^{\prime \prime}$ wood in Quebec is a pile $8 \mathrm{ft} . \mathrm{x} 4 \mathrm{ft}$. $\times 16^{\prime \prime}$, or actually $1 / 3$ of a standard cord, and that is what is delivered if a cord of $16^{\prime \prime}$ wood, is ordered.

With all the various measurements and practices to contend with it is not an easy matter to set ceiling prices based on standardization without educating the public beforehand. Because of the urgency of setting ceiling prices as quickly as possible, this process of education had to be left in abeyance with the hope that the selling and buying public would accept the necessary changes.

Quality and grades of fuelwood have never been standardized, and won't be for many years, although the necessity for standardization has been apparent. Competition has acted as a measure of control, but there has never been any attempt to set up definite standards. In some localities any wood is fuel wood. This applies primarily to those areas where wood fuel is more or less a luxury, used only in fireplaces and for spring and fall burning in coal furnaces. Under such circumstances fuelwood is sold at an uneconomic price and the buying public is satisfied to pay large prices for small deliveries, such as is practised in Toronto or Montreal. Here wood is sold by the bag-supposedly 2 cubic feet per bag-at three bags for a dollar. Such small deliveries are usually made along with a coal order.

Service charges are high in connection with the handling of wood, and vary with the size of the city in which the wood is sold. Taken generally, the difference between the producer's price and the consumer's is $100 \%$, but in some cities it is nearly $200 \%$, most of which is made up of handling charges.

It may be of interest to sketch roughly how ceiling prices for fuelwood are set. Two price schedules are set. The first covers those prices that may be charged by the farmer or producer, for fuelwood placed or piled on a truck road; the second states those prices that may be charged by the retailer when delivering to the consumer. In setting the "producer" price such items are considered as (1) stumpage; (2) cutting in the woods; (3) hauling to a truck road; (4) allowance for holding until dry; (5) profit. The same items are allowed whether the producer wood is sold by a farmer or a contractor. These prices are for 4-ft. wood. If the producer sells in any length under four feet, an allowance is made for (1) sawing; (2) splitting (if kitchen wood); and (3) 10 per cent shrinkage.

The items that figure in the cost to the dealer are (1) trucking or freight from producer to dealer; (2) maintenance of wood yard; (3) insurance; (4) maintenance of buildings; (5) delivery from wood yard to consumer; (6) profit.

All of these charges differ according to the area or municipality under consideration and control the ceiling prices set. The more dense the population, the greater the service charges.

Fortunately, investigators connected with the Wartime Prices and Trade Board can examine books or contracts when and where necessary. This 
applies to any business. If the dealer refuses to give what is considered true information, an auditor can be placed in his office to examine his books. Due to this known fact there is little trouble in obtaining any in. formation needed.

Although the cord as a unit of measurement was standardized under the "Weights and Measures Act" in 1935 the use of the unit was never enforced. It was because of this that it was deemed necessary, before even attempting to place ceiling prices for fuelwood, to have an order passed making it illegal, in the future, to sell fuelwood of any sort other than sawdust and hogged fuel, by any measurement other than the standard cord or fraction of same. This means that wood cannot be sold by the load in the future. This law will, of course, benefit the consumer, who in the past has paid exorbitant prices by purchasing loads of unknown quantity.

The foregoing gives some idea of the problems met with in attempting to set ceiling prices for wood fuel-such prices as will be satisfactory to the producer, the retailer and, last but not least, the consumer. 